\title{
PROGRAM PELATIHAN KETERAMPILAN TATA RIAS PENGANTIN DALAM UPAYA PENINGKATAN PENDAPATAN MASYARAKAT (Studi Kasus Penelitian pada Peserta Didik di LKP HENNY'S Kota Cimahi)
}

\author{
Tiktik Regina Dewi Anjani1, Irfa Dorojatun² \\ 1,2IKIP Siliwangi \\ 1tiktikregina1@gmail.com
}

\begin{abstract}
ABSTRAK
Pendidikan Luar Sekolah adalah salah satu jalur pendidikan yang bertugas mencerdaskan kehidupan bangsa dengan tujuan memberikan kesempatan belajar seluas-luasnya bagi masyarakat. Jalur pendidikan luar sekolah merupakan pendidikan yang diselenggarakan di luar sistem pendidikan sekolah melalui kegiatan belajar mengajar yang dilaksanakan berdasarkan kebutuhan warga belajar. Pendidikan luar sekolah berhubungan dengan pendidikan kecakapan hidup, dalam hal ini penulis meneliti sebuah pelatihan tata rias pengantin yang diselenggarakan di LKP Henny's dengan jumlah warga belajar berjumlah 20 orang dengan tutor/tenaga pengajar berjumlah 4 orang. Tujuan penelitian ini adalah untuk mengetahui sejauhmana peningkatan pendapatan masyarakat setelah mengikuti pelatihan tata rias pengantin. Teori yang digunakan dalam penelitian ini di antaranya adalah teori pelatihan, kecakapan hidup dan kewirausahaan. Peneitian ini menggunakan metode deskriptif kualitatif, yaitu melakukan penelitian dengan tujuan ingin menggambarkan masalah dan melakukan analisis terhadap masalah. Masyarakat sebagai lingkungan memiliki pengaruh besar terhadap perkembangan pribadi seseorang. Masyarakat mempunyai peranan penting dalam upaya ikut serta menyelenggarakan pendidikan, karena membantu pengadaan sarana dan prasarana dan menyediakan lapangan kerja. Sistem pendidikan nasional mengisyaratkan bahwa pendidikan seumur hidup dikelola atas tanggung jawab keluarga, sekolah dan masyarakat. Dimana masing-masing mempunyai tanggung jawab yang terpadu dalam rangka pencapaian tujuan nasional.
\end{abstract}

Kata kunci: keterampilan, pelatihan, pendapatan masyarakat, tata rias pengantin

\section{PENDAHULUAN}

Pendidikan Luar Sekolah adalah salah satu jalur pendidikan yang bertugas mencerdaskan kehidupan bangsa dengan tujuan memberikan kesempatan belajar seluas-luasnya bagi masyarakat. Soedijanto (Sihombing, 1999) menyebutkan bahwa tujuan pendidikan luar sekolah memberikan kesempatan belajar yang seluas-luasnya bagi masyarakat yang karena berbagai faktor seperti kesulitan ekonomi, sosial dan lingkungan yang kurang mendukung tidak mendapat kesempatan untuk mengikuti pendidikan melalui jalur pendidikan sekolah. 
Salah satu fokus analisis dalam pengembangan kurikulum pendidikan yang menekankan pada kecakapan hidup atau bekerja, karena kecakapan hidup memiliki makna yang lebih luas dari employability skills dan vocational skills, serta memberikan pelayanan kepada peserta didik, yang ingin mendapatkan keterampilan untuk bekal dalam meningkatkan taraf hidupnya sehingga bisa mengatasi masalah didalam kehidupannya. Kecakapan hidup/life skills juga mengarahkan pada kegiatan pembelajaran agar sumber daya manusia memiliki kreativitas, mandiri, punya etos kerja serta mampu melihat peluang sehingga dapat menghasilkan warga belajar yang tangguh dan mampu menantang serta menghadapi masa depan untuk bisa berpendapatan yang lebih layak.

Di dalam kehidupan nyata salah satu upaya yang perlu dilakukan adalah mendekatkan pendidikan (kegiatan belajar mengajar) dengan kehidupan nyata yang memiliki nilainilai preservative dan progresif sekaligus melalui pengintensifan dan pengefektifitasan pendidikan kecakapan hidup, sehingga penting sekali pendidikan kecakapan hidup dilakukan untuk meningkatkan keterampilan, pengetahuan dan sikap masyarakat di bidang pekerjaan/usaha sesuai dengan bakat, minat sesuai potensi lingkungannya sehingga mereka memiliki bekal kemampuan untuk bekerja ataupun usaha mandiri untuk meningkatkan kualitas hidupnya yang akan berdampak kepada pendapatannya.

Salah satu aspek positif sebagai akibat pengaruh pendidikan terhadap Sumber Daya Manusia (SDM) adalah peningkatan mutu kerjanya, menurut (Andreas, 1990) mengemukakan bahwa pendidikan mempengaruhi keterampilan, sehingga berkaitan dengan kualitas tenaga kerja dalam masyarakat dapat dilihat dari peningkatan pendapatannya, ini membuktikan bahwa pendapatan yang mempunyai keterampilan lebih besar dibandingkan dengan yang tidak mempunyai pendidikan maupun keterampilan.

Keberadaan pendidikan luar sekolah, dalam rangka pengembangan sumber daya manusia Indonesia, dapat dilihat dalam Undang-undang No. 20 tahun 2003 tentang Sistem Pendidikan Nasional, bagian kelima pasal 26, menyebutkan (1) Pendidikan nonformal diselenggarakan bagi warga masyarakat yang memerlukan layanan pendidikan, yang berfungsi sebagai pengganti, penambah dan pelengkap pendidikan formal, dalam rangka mendukung pendidikan sepanjang hayat, (2) Pendidikan nonformal berfungsi mengembangkan potensi peserta didik dengan penekanan pada penguasaan pengetahuan dan keterampilan fungsional serta pengembangan sikap dan kepribadian profesional. (3) Pendidikan nonformal meliputi pendidikan kecakapan hidup, pendidikan anak usia dini, pendidikan kepemudaan, pendidikan pemberdayaan perempuan, pendidikan keaksaraan, pendidikan keterampilan dan pelatihan kerja, pendidikan kesetaraan, serta pendidikan lain yang ditujukan untuk mengembangkan kemampuan peserta didik. (4) Pendidikan nonformal memiliki satuan pendidikan yang terdiri dari lembaga kursus, lembaga pelatihan, kelompok belajar, pusat kegiatan belajar masyarakat, dan majelis taklim serta berbagai satuan pendidikan sejenis.

Dari empat butir tentang pendidikan nonformal yang telah disebutkan di atas, maka dapat dikemukakan bahwa salah satu bentuk layanan pendidikan nonformal bagi warga masyarakat yang berfungsi sebagai pengganti, penambah dan pelengkap pendidikan 
formal yang dilakukan secara terstruktur dan berjenjang dalam rangka mendukung pendidikan sepanjang hayat adalah pendidikan kesetaraan.

Berdasarkan uraian di atas, maka penulis ingin mengungkapkan bagaimana pelatihan keterampilan tata rias pengantin yang berorientasi pada kecakapan hidup atau life skills dapat meningkatkan pendapatan peserta didik. Dalam penelitian ini penulis akan mengkaji pembelajaran keterampilan tata rias pengantin sebagai salah satu bentuk pembelajaran kecakapan hidup yang diselenggarakan oleh Lembaga Kursus dan Pelatihan (LKP) HENNY'S di Kota Cimahi.

\section{LANDASAN TEORI}

\section{Pengertian Lingkungan dan Lembaga Pendidikan}

Lingkungan pendidikan dapat diartikan sebagai faktor-faktor yang berpengaruh terhadap praktek pendidikan baik positif ataupun negatif. Lingkungan pendidikan sebagai tempat berlangsungnya proses pendidikan, merupakan bagian dari lingkungan sosial. Lingkungan pendidikan sangat dibutuhkan dalam proses pendidikan sebab lingkungan pendidikan tersebut berfungsi menunjang proses belajar mengajar secara nyaman, tertib, dan berkelanjutan. Dengan suasana seperti itu, maka proses pendidikan dapat dilaksanakan.

Lembaga pendidikan adalah suatu badan yang berusaha mengelola dan menyelenggarakan kegiatan-kegiatan sosial, kebudayaan, keagamaan, keterampilan dan keahlian. yaitu dalam hal pendidikan intelektual, spiritual, serta keahlian/ keterampilan. Sebagai tempat atau wadah dimana orang-orang berkumpul, bekerjasama secara rasional dan sistematis, terencana, terorganisasi, terpimpin dan terkendali, dalam memanfaatkan sumber daya, sarana-parasarana, data, dan lain sebagainya yang digunakan secara efisien dan efektif untuk mencapai tujuan pendidikan.

\section{Fungsi dan Peranan Lembaga Pendidikan keterampilan}

Secara umum fungsi lingkungan pendidikan adalah membantu peserta didik dalam interaksi dengan berbagai lingkungan sekitarnya. Didalam UU no 2 tahun 1989 tentang system Pendidikan Nasional menyebutkan bahwa penyelenggaraan pendidikan dilaksanakan melalui dua jalur, yaitu jalur pendidikan sekolah dan jalur pendidikan luar sekolah. Jalur pendidikan luar sekolah merupakan pendidikan yang diselenggarakan di luar sekolah melalui kegiatan belajar mengajar yang tidak harus berkesinambungan.Satuan pendidikan luar sekolah meliputi kursus/lembaga pendidikan keterampilan dan satuan pendidikan yang sejenis.

\section{a. Program Pendidikan Kecakapan Hidup}

Pendidikan kecakapan hidup dijalur Non Formal bertujuan untuk meningkatkan keterampilan, pengetahuan, dan sikap warga belajar dibidang pekerjaan/usia tertentu sesuai dengan bakat, minat, perkembangan fisik dan jiwanya, serta potensi lingkungannya sehingga peserta program memiliki bekal kemampuan untuk bekerja atau berusaha mandiri yang dapat dijadikan bekal untuk meningkatkan kualitas hidupnya. 


\section{b. Program Kursus Para Profesi}

Program ini merupakan konsep pendidikan kecakapan hidup yang menerapkan metode pendekatan yang bersifat terpadu dari komponen pelatihan, komponen sertifikasi dan komponen penempatan.Konsep ini sering disebut dengan istilah strategi “ 3 in 1".

Komponen pertama yaitu pelatihan dilaksanakan oleh Lembaga Pendidikan Kursus. Komponen kedua yaitu pelatihan diselenggarakan dengan menggunakan kurikulum berbasis kompetensi dan didukung tenaga pendidik yang memiliki kualifikasi dan kompetensi yang sesuai. Komponen ketiga yaitu penempatan yang dilaksanakan oleh Dunia Usaha Dunia industri (DUDI) dalam dan luar negeri. Sasaran program ini adalah pengangguran usia produktif yang memiliki latar belakang pendidikan minimal SLTP.

\section{c. Program Kewirausahaan}

Program Pendidikan Kecakapan Wirausaha (PKW) adalah jenis kursus/jenis program yang diselenggarakan secara khusus untuk memberikan kesempatan masyarakat dipedesaan/perkotaan agar memperoleh pengetahuan kewirausahaan.

\section{METODE PENELITIAN}

Desain penelitian merupakan tahapan kegiatan peneliti dalam melaksanakan penelitian yang dimulai dari awal sampai akhir penelitian, yang tujuannya untuk memberikan gambaran tentang keseluruhan mulai dari perencanaan, pelaksanaan, pengumpulan data, sampai dengan tahap penulisan laporan.

Menurut (Moleong, 2013), memaparkan bahwa terdapat empat tahapan yang dilakukan dalam penelitian, yaitu sebagai berikut :

\section{Tahap pra-lapangan}

Tahap pra-lapangan adalah tahap awal dalam melakukan sebuah penelitian. Pada tahap awal ini peneliti melakukan kegiatan observasi langsung ke lokasi penelitian yaitu Lembaga Keterampilan dan Pelatihan Henny's yang berlokasi di Jl. Pesantren No. 36A, Cibabat Cimahi. kegiatan observasi ini dilakukan agar peneliti dapat menyaksikan secara langsung gambaran awal tentang pokok permasalahan yang terdapat dilokasi yang akan dijadikan tempat penelitian. Setelah fokus terhadap penelitian, peneliti meminta data lulusan pelatihan yang telah berhasil dalam mengimplementasikan pelatihan untuk dikaji lebih lanjut.

\section{Tahap Rancangan dan Pelaksanaan Lapangan}

Pada tahap rancangan dan pelaksanaan lapangan, peneliti melakukan penggalian informasi data secara keseluruhan dan mendalam dengan mengenal lebih dekat kepada subjek penelitian, mengadakan pengamatan dengan melakukan wawancara lulusan peserta didik LKP Henny's. Pada tahap ini merupakan kegiatan umum dan pengumpulan data dan melakukan analisis data terhadap hasil pengumpulan data tersebut. 
3. Tahap Analisis Data

Pada tahap analisis data peneliti melakukan kegiatan analisis terhadap data yang telah diperoleh dari lapangan. Kegiatan menganalisis data adalah sebuah tahap yang sangat menentukan dalam mencari jawaban atas permasalahan penelitian yang diperoleh dilapangan. Proses analisis data dimulai dari menelaah seluruh data yang tersedia dari berbagai sumber, yaitu dari hasil wawancara, pengamatan, dokumen pribadi, serta dokumen resmi yang terdapat dilapangan. Data yang telah dikumpulkan tersebut kemudian diolah sesuai dengan kaidah pengolahan yang relevan dengan pendekatan penelitian kualitatif.

\section{HASIL DAN PEMBAHASAN Hasil}

\section{Program dan Pengembangan Lembaga Kursus dan Pelatihan (LKP) Henny's}

Sampai tahun 2018, program dan pengembangan Lembaga Kursus dan Pelatihan (LKP) Henny"s dilaksanakan melalui kegiatan Kursus dan Pelatihan Keterampilan Tata Rias Pengantin Level 1 sebagai asisten penata rias, Level 2 sebagai penata rias dan Level 3 sebagai pengusaha jasa rias pengantin. Dengan program pengembangan Tata Rias dan Tata Rias Pengantin serta mengelola usaha salon.

\section{Pemanfaatan Kursus Tata Rias Pengantin Dalam Rangka Memperoleh Penghasilan Nafkah untuk Kelangsungan Hidupnya}

Kegiatan pelatihan kursus tata rias pengantin puteri di LKP Henny"s memberikan dampak positif, dimana dapat di lihat dari peningkatan taraf hidup dan peningkatan sosial. Peningkatan taraf hidup terjadi dalam perekonomian keluarga dengan cara membuka usaha sendiri di bidang tata rias pengantin sesuai dengan kemampuan pengetahuan yang telah di dapat di pelatihan kursus.

Pemanfaatan pengetahuan tata rias pengantin ini akan mendapatkan penghasilan sendiri untuk membantu memenuhi kebutuhan hidupnya sampingan sebagai ibu rumah tangga. Peningkatan aspek sosial pun akan terjadi dengan mengikuti pelatihan kursus tata rias pengantin, dimana orang akan dihargai oleh masyarakat sekitar atas kemampuan pengetahuan tata rias pengantinnya dan pemberbanyak teman tata rias pengantin.

Apabila kemampuannya usahanya dikembangkan dengan penambahan fasilitas dan kualitas tata rias pengantinnya di tingkatkan dengan adanya penambahan modal sedikit demi sedikit. Modal awal bisa dimulai dengan biaya sekitar Rp 500.000,- untuk pembelian make-up yang mungkin bisa digunakan untuk 5 kali pemakaian. Apabila dengan penambahan modal bisa digunakan untuk memenuhi sarana dan prasarana penunjang seperti aksesoris, sanggul, roncean, busana dan lain-lain.

Promosi yang lebih baik selain promosi dari mulut ke mulut atau dari teman ke teman. Promosi kepada pelanggan juga bisa menggunakan brosur, melalui kemitraan, kerja sama dengan salon, mengikuti perias senior sebagai asisten atau mengikuti pameran. 


\section{Hasil yang diperoleh dari Pemanfaatan Kursus Tata Rias Pengantin}

Hasil pelatihan kecakapan hidup melalui pembelajaran tata rias pengantin dilihat dari pelaksanaan pembelajaran, adanya serapan bahan beajar yang dapat dicapai oleh umumnya peserta pelatihan dengan terpenuhinya standar kompetensi seperti yang diatur dalam Buku Kurikulum Berbasis Kompetensi (KBK) dan

Buku Standar Kompetensi Kerja Nasional Indonesia (SKKNI). Penyerapan pelatihan kecakapan hidup dapat dilihat dari kemampuan beradaptasi dari pembelajaran tata rias pengantin sesuai dengan buku KBK bagian umum dan buku SKKNI yang di contohkan/simulasi antara sesama peserta pelatihan dan dengan instruktur, kemampuan bekerja sama dari pembelajaran tata rias pengantin sesuai dengan contoh/ simulasi koordinasi antaralembaga/instansi terkait dalam kegiatan tata rias pengantin. Dalam tata rias itu sendiri peserta pelatihan umumnya dapat mengikuti tahapan pelatihan merias wajah baik penguasan teori maupun alat dan bahan make-up yang dipakai, termasuk dalam menata rambut dan, menata busana serta aksesoris. Sehingga adanya peningkatan pengetahuan dan keterampilan peserta pelatihan dalam kecakapan hidup untuk kemampuan beradaptasi, berkomunikasi, dan bekerja sama.

\section{Upaya Pengembangan Usaha Pemanfaatan Hasil Kursus Tata Rias Pengantin}

Dalam pembelajaran tata rias pengantin remaja putus sekolah sebagai peserta pelatihan setelah mengikuti tahapan pembelajaran merias pengantin yaitu yang diawali dengan pembelajaran merias wajah baik penguasan teori maupun alat dan bahan make-up yang dipakai, termasuk dalam menata rambut dan menata busana serta aksesoris. Terdapat dampak adanya peningkatan pengetahuan dan keterampilan peserta pelatihan dalam kecakapan hidup untuk kemampuan beradaptasi, berkomunikasi, dan bekerja sama.

\section{Pembahasan}

Menurut (Simamora, 1995) yang mengartikan "pelatihan sebagai serangkaian peningkatan pengetahuan, pengalaman, ataupun perubahan sikap seorang individu". Dengan demikian peserta pelatihan dapat meningkatkan kemandiriannya serta pengetahuannya dan pemahaman dalam kecakapan hidup untuk kemampuan adaptasi dengan lingkungan yang ada, berkomunikasi serta bekerja sama dalam bekerja untuk menunjang pekerjaan tata rias pengantin.

Mandiri menciptakan kerja untuk diri sendiri, maupun berkembang menjadi wiraswasta yang mampu menciptakan lapangan kerja bagi orang lain ataupun mampu menjadi cendikiawan, manusia yang berkreasi, inovatif, melalui ide idenya atau hasil penemuannya, menjadikan masyarakat lebih baik; baik dalam bentuk inovasi teknologi, ataupun inovasi ilmu yang mampu mengembangkan ilmu lebih maju, sebagai upaya preventif maupun represif untuk kelangsungan hidup sumber daya manusia". Jiwa mandiri tumbuh dan berkembang seiring dengan tumbuhnya konsep wirausaha, yang harus mempunyai jiwa mandiri atau kemandirian sebagai kepribadian atau sikap mental yang harus dimiliki oleh setiap orang yang didalamnya terkandung unsur-unsur dengan watak-watak yang perlu dikembangkan agar tumbuh menyatu dalam setiap gerak kehidupan manusia.

Asumsi tersebut menurut (Kamil, 2010) menunjukkan bahwa : 
Kemandirian dapat menentukan sikap dan perilaku seseorang, sehingga kemandirian merupakan jiwa yang dapat tumbuh dan berkembang seiring pemahaman tentang konsep hidup yang mengarah pada kemampuan, kemauan, keuletan, ketekunan, dalam menekuni bidang yang digeluti sehingga berhasil memiliki jiwa mandiri.

Dalam pemanfaatan kursus tata rias pengantinnya itu sendiri diperlukan kemandirian yang dapat lebih mengetahui, memahami dan mampu untuk mengerjakan merias wajah, rias rambut, menata busana dan aksesorisnya, sesuai dengan tahapannya untuk kebutuhan tata rias pengantin.

Menurut (Sudjana, 2010) disebutkan bahwa :

Untuk kelancaran keterampilan gerak diperlukan berbagai faktor yaitu dorongan yang kuat, keinginan, kecepatan, ketepatan, kelincahan, koordinasi dan fleksibilitas. Faktor-faktor ini berhubungan dengan bagianbagian tubuh seperti mata, mulut, telinga dan tangan serta berkaitan pula dengan pertumbuhan badan peserta didik sebelum keterampilan gerak itu dipelajari peserta didi.

Kebehasilan bisa diukur secara bertahap. Untuk melakukan perubahan perilaku menurut (Musa, 2010), diperlukan unsur-unsur pendukung sebagai berikut :

(1) Sikap yaitu nilai-nilai yang dianut oleh seseorang, (2) Pengetahuan yaitu pengalaman, informasi, dan wawasan yang menjadi bahan baku sikap seseorang, (3) Keterampilan yaitu kemampuan teknis yang membantu seseorang menerapkan pengetahuannya, (4) Material yaitu bahan dan peralatan yang dibutuhkan untuk melakukan sesuatu.

Dalam pelatihan orang dewasa diperlukan perhatian terhadap pengembangan sikap, pengetahuan, keterampilan dan material pendukung yang diperlukan agar peserta pelatihan siap melakukan sesuatu. Setiap manusia memiliki perilaku yang sudah ada. Karena itu, pelatihan orang dewasa melakukan perubahan perilaku yang dapat digambarkan menurut (Musa, 2010) sebagai berikut : “ (1) Perilaku kini dilandasi oleh pengetahuan, sikap kini, keterampilan kini, material kini dan (2) perilaku baru didorong oleh sikap baru,keterampilan baru, material baru. Pelatihan kecakapan hidup (life skills) sebagai usaha untuk terjadinya proses belajar individu atau kelompok.

Pelatihan adalah usaha berencana yang diselenggarakan supaya dicapai penguasaan keterampilan, pengetahuan, dan sikap yang relevan dengan kebutuhan peserta pelatihan. Umumnya pelatihan dilakukan untuk pendidikan jangka pendek dengan prosedur yang sistematis dan terorganisir untuk tujuan tertentu. Pendidikan dalam bentuk pelatihan, relevan diberikan kepada masyarakat lapisan bawah seperti perempuan remaja putus sekolah usia nya produktif di kota Cimahi untuk mempelajari keterampilan hidup (life skills).

Kegiatan pendidikan pelatihan yang berjangka pendek tidak membosankan peserta dan hasilnya dapat dengan cepat dinikmati. Pelatihan dilaksanakan untuk memberikan kecakapan hidup dan keterampilan tata rias pengantin untuk supaya mampu hidup mandiri. 
Dengan demikian peserta pelatihan dapat meningkatkan kemandiriannya serta pengetahuan dan pemahaman dalam kecakapan hidup untuk kemampuan adaptasi dengan lingkungan yang ada, berkomunikasi serta bekerja sama dalam bekerja untuk menunjang dalam pekerjaan tata rias pengantin.

Dari hasil penelitian kemandirian remaja putus sekolah sebagai dampak adanya pelatihan kecakapan hidup melalui pembelajaran tata rias pengantin, dikemukakan sebanyak 16 orang peserta pelatihan atau $80 \%$ nya dapat memperlihatkan adanya kemampuan untuk mandiri dan 4 orang peserta atau $20 \%$ nya belum mampu mandiri. Hal ini dilihat dari karakteristik individu yang mampu bekerja mandiri dengan tidak tergantung pada orang lain dalam melaksanakan keterampilan merias pengantin dari hasil pelatihan kecakapan hidup yang melalui kemampuan berkomunikasi, beradaptasi dan bekerja sama.

\section{KESIMPULAN}

Berdasarkan hasil penelitian kepada peserta alumni pelatihan kursus tata rias pengantin sunda puteri berjangka pendek di LKP Henny's Kota Cimahi terhadap pemanfaatan hasil kursus tata rias pengantin sunda puteri dalam konteks kemandirian usaha disimpulkan sebagai berikut :

\section{Pengetahuan dan Keterampilan yang dimiliki lulusan sebagai hasil belajar kursus pengantin yang ditempuhnya.}

Manfaat hasil pelatihan tata rias pengantin sunda puteri di tinjau dari pengetahuan dan keterampilan dalam penguasaan teknik tata rias pengantin menunjukkan sebagaian besar peserta sudah memahami teknik-tekniknya untuk merias pengantin yang sangat bermanfaat sekali untuk jangka panjang dalam konteks kemandirian yaitu dengan membuka usaha pengantin. Pengetahuan dan keterampilan tersebut di tunjukkan dengan penguasaan kemampuan untuk melakukan cara kerja atau tahapan-tahapan merias dengan hasil tata rias yang bagus dan rapih mulai dari persiapan alat-alat makeup, kosmetik, aksesoris, sanggul, dan busana.

\section{Para lulusan memanfaatan hasil kursus pengantin dalam rangka memperoleh penghasilan untuk kelangsungan hidup}

Dengan adanya pemanfaatan hasil kursus tata rias pengantin diharapkan para peserta dapat mandiri untuk membuka usaha sampingan seperti usaha salon, usaha wedding (pernikahan), perias profesional. Pengembangan usaha ini akan memberikan dampak yang positif, dilihat dari peningkatan tarap hidup dalam perekonomian keluarga, dengan mendapatkan penghasilan lebih (nafkah) untuk memenuhi kebutuhan hidup, dan peningkatan aspek sosial dimana orang yang mempunyai kemampuan lebih dalam tata rias pengantin akan dihargai masyarakat sekitar dan mempunyai banyak teman untuk berbagi pengetahuan sekitar tata rias.

\section{Hasil yang diperoleh dari pemanfaatan kursus pengantin.}

Pemanfaatan hasil kursus tata rias pengantin sunda puteri akan memberikan rasa percaya diri peserta pelatihan untuk bisa mandiri dan yakin akan kemampuannya untuk membuka usaha. Rasa percaya diri para peserta kursus akan mendorong peserta untuk terus mengembangkan pengetahuan nya dengan terus bertukar pikiran antar sesama 
atau dengan senior/mentor profesional berpengalaman dalam bidang wedding (pernikahan).

\section{DAFTAR PUSTAKA}

Andreas, H. G. (1990). PVC Stabilizer and Plastics and Additives Handbook. Germany: Hanser Publisher, Munich.

Ansori, A \& Samsudin, A. (2013). TRANSFORMASI PEMBELAJARAN DI PENDIDKAN NON FORMAL (Upaya mempersiapkan pendidik dan peserta didik dalam menghadapi tantangan global untuk menjadi manusia pembelajar). Empowerment, 2(1), 1-15.

Fajar, M. (2002). Laporan Menteri Pendidikan Nasional Pada Rapat Koordinasi Bidang Kesra Tingkat Menteri. Depdiknas: Jakarta.

Kamil, M. (2010). Model Pendidikan dan Pelatihan (Konsep dan Aplikasi). Bandung: Alfabeta.

Moleong, L. J. (2013). Metode Penelitian Kualitatif. Edisi Revisi. Bandung: PT Remaja Rosdakarya.

Musa, S. (2010). Seni Dan Teknik Fasilitator : Pendidikan Orang Dewasa. Bandung: YPIN Indonesia.

Saepudin, A \& Mulyono, D. (2019). COMMUNITY EDUCATION IN COMMUNITY DEVELOPMENT. Empowerment, 8(1), 65-73

Samani, H. M. (2002). Konsep dan Model Pendidikan Karakter. Remaja Rosdakarya.: Bandung.

Sihombing, U. (1999). Pendidikan Luar Sekolah Kini dan Masa Depan. Jakarta: Mahkota. Simamora, H. (1995). Manajemen Sumber Daya Manusia. Yogyakarta: STIE YKPN. Sudjana, D. (2010). Metode dan Teknik Pembelajaran Partisipatif. Bandung: Falah Production.

Suparman, \& dkk. (Pendidikan Karakter Mandiri Dan Kewiraswastaan). 2003. Bandung: Angkasa. 